\title{
NORMA PERSATUAN SEBAGAI BATASAN PERBUATAN PIDANA PENYEBARAN UJARAN KEBENCIAN MELALUI INTERNET
}

\author{
Hwian Christianto \\ Fakultas Hukum, Universitas Surabaya \\ email: hwall4jc@yahoo.co.id
}

disampaikan 21/9/19 - di-review 8/1/20 - diterima 31/5/2020

DOI: $10.25123 /$ vej.3501

\begin{abstract}
The Law no 11 of 2008 contains a penal rule against spreading hatred by the means of the internet (or digital social media). The enforcement of this penal sanction, due to its vagueness on the meaning of the term hate and spread of hate, consequently result in a public debate on how it impacts on people's right of free expression. Apparently this vagueness opens up the possibility to limit even suppress freedom of expression. Using a juridical normative approach, this article discusses the leitmotiv of the above penal sanction. The author suggests that the express purpose of this article is to secure the unity and integrity of a pluralistic society.
\end{abstract}

Keywords:

hate crimes, unity, integrity, pluralistic society

\begin{abstract}
Abstrak
Undang-Undang No. 11 Tahun 2008 memuat satu ketentuan yang mengancam dengan sanksi pidana perbuatan menyebar kebencian melalui internet. Di dalam praktik penegakan aturan memunculkan pertanyaan tentang seberapa jauh hal ini membatasi kebebasan berekspresi. Fakta dilapangan menunjukkan adanya ketidakpastian tentang batasan pengertian kebencian dan penyebaran kebencian melalui internet. Ketidakpastian batasan ini membuka peluang untuk membatasi dan memberangus kebebasan berekspresi. Tulisan ini dengan metode yuridis normatif, menelaah gagasan yang melandasi ketentuan pidana ini. Satu hal yang terungkap adalah bahwa tujuan adanya ketentuan pidana tersebut terutama adalah untuk menjaga dan memelihara persatuan dan kesatuan bangsa dalam masyarakat yang bercirikan kemajemukan.
\end{abstract}

Kata Kunci:

penyebaran ujaran kebencian; nilai persatuan Indonesia; perbuatan pidana

\section{Pendahuluan}

Keberadaan manusia bersama manusia lainnya selalu berisiko menimbulkan gesekan kepentingan berujung pada perdamaian dengan sikap saling memahami atau berujung pada pertikaian yang dilandasi sikap penolakan terhadap perbuatan yang dinilai merugikan kepentingan diri. Kondisi masyarakat Indonesia yang terdiri dari beribu suku, beragam bahasa dan berbagai macam latar belakang budaya merupakan tantangan tersendiri untuk dapat hidup dalam 
sebuah institusi sosial, masyarakat. Perbedaan yang ada dapat menjadi materi yang sangat reaktif bagi munculnya konflik antar golongan atau kelompok yang justru merugikan bangsa Indonesia sendiri. Berbagai macam ketentuan hukum diberlakukan oleh Pemerintah sebagai upaya mencegah dan menanggulangi perpecahan antar golongan ini termasuk di dalamnya ketentuan hukum pidana. Mulai dari Kitab Undang-Undang Hukum Pidana (KUHP) yaitu Pasal 156 KUHP (perbuatan menyatakan permusuhan terhadap golongan masyarakat), Pasal 156a KUHP (perbuatan menyatakan permusuhan terhadap agama yang dianut di Indonesia) serta Pasal 157 KUHP (perbuatan mempublikasikan pernyataan permusuhan terhadap golongan masyarakat) sampai beberapa Undang-Undang pidana khusus (Undang-Undang Nomor 40 Tahun 2008 tentang Penghapusan Diskriminasi Ras dan Etnis/UU PDRE) menyebutkan secara eksplisit larangan perbuatan menganggu keberagaman yang ada di masyarakat Indonesia.

Era globalisasi informasi yang menghadirkan kecanggihan teknologi informasi pun tidak ketinggalan menghadirkan sebuah realitas baru berupa masyarakat internet atau netizen dengan fasilitas kecepatan, kemudahan dan ruang wilayah yang tidak terbatas pada satu negara dalam memperoleh informasi. Walaupun internet menghadirkan sebuah realitas masyarakat baru tidak berarti aman dari perbuatan yang menyerang atau mengganggu perbedaan yang ada. Perbedaan justru muncul ke permukaan sebagai bahan pembicaraan mulai dari individu kepada individu lain, individu kepada kelompok masyarakat sampai pada masyarakat sebuah negara.

Risiko munculnya perbuatan menyerang orang lain atau kelompok tertentu justru dinilai sebagai hal yang sangat penting untuk diatur dalam Undang-Undang Nomor 11 Tahun 2008 tentang Informasi dan Transaksi Elektronik yang selanjutnya diubah melalui Undang-Undang Nomor 19 Tahun 2016 tentang Perubahan Undang-Undang Informasi dan Transaksi Elektronik (UU ITE) secara khusus Pasal 28 ayat (2). Pemberlakuan ketentuan hukum ini pada perjalanannya menghadirkan permasalahan terkait ukuran mana yang digunakan untuk menilai suatu perbuatan sebagai perbuatan yang menimbulkan rasa kebencian atau permusuhan indivividu dan/atau kelompok masyarakat tertentu berdasarkan 
Suku, Agama, Ras dan Antar golongan (SARA). Kasus ADP yang mengunggah kalimat "Siapa saja dukung penista agama adalah bajingan yang perlu diludahi mukanya-ADP" dalam akun media sosial Twitter merupakan salah satu kasus ujaran kebencian yang menimbulkan perdebatan. ADP memang diputus terbukti melanggar Pasal 45 ayat (2) jo. Pasal 28 ayat (2) UU ITE oleh Pengadilan Negeri Jakarta Selatan Nomor 370/Pid.Sus/2018/PN.Jkt.Sel tanggal 28 Januari 2019 walau demikian perdebatan masih muncul terkait ukuran penilaian ujaran kebencian yang digunakan. ${ }^{1}$ Tim Kuasa Hukum ADP dalam pembelaannya menyatakan keberatan karena ia menilai pernyataannya sebagai bagian dari kebebasan berpendapat. ${ }^{2}$ Kasus ujaran kebencian terhadap golongan masyarakat juga terjadi pada perbuatan AT yang diketahui dari video saat memberikan ceramah di Masjid Mujahidin, Surabaya melalui media sosial YouTube mengatakan "Jokowi adalah PKI, China PKI, Ahok harus dipenggal kepalanya dan Kapolda Metro Jaya diindikasikan PKI". ${ }^{3}$ Ketua Majelis Hakim Agung pada Tingkat Kasasi menyatakan bahwa perbuatan AT masuk klasifikasi kasus Penghapusan Diskriminasi Ras dan Etnis pada Putusan Mahkamah Agung Republik Indonesia Nomor 1167K/PID.SUS/2018. ${ }^{4}$ Pertimbangan yang menarik jika melihat pernyataan AT tidak hanya mengarah pada perbuatan Diskriminasi Ras dan Etnis melainkan perbuatan ujaran kebencian.

Kedua contoh kasus tersebut menunjukkan penilaian suatu perbuatan yang didasarkan pada ukuran yang tidak jelas pada gilirannya menimbulkan ketidakpastian hukum baik bagi tersangka/terdakwa, maupun masyarakat lebih luas. Tersangka/terdakwa mengalami ketidakpastian hukum akan ukuran yang digunakan untuk mengatakan perbuatannya sebagai terlarang sedangkan

1 Pebriansyah Ariefana, Isi Lengkap Putusan Banding Kasus Ujaran Kebencian Ahmad Dhani, https://www.suara.com/news/2019/03/13/174931/isi-lengkap-putusan-banding-kasusujaran-kebencian-ahmad-dhani, diakses 28 Februari 2020

2 Nina Atmasari, ed., Bantah Lakukan Ujaran Kebencian, Ahmad Dhani Anggap Cuitannya Wajar, https://news.harianjogja.com/read/2018/12/11/500/958068/bantah-lakukan-uahmaddhani-anggap-cuitannya-wajar-, diakses 28 Februari 2020

3 Rivki, Alfian Tanjung: Lepas di Kasus PDI Dihukum karena Fitnah Jokowi, https://news.detik.com/berita/d-4060805/alfian-tanjung-lepas-di-kasus-pdip-dihukumkarena-fitnah-jokowi, diakses 28 Februari 2020

4 Id. 
masyarakat menjadi tersulut untuk bereaksi negatif padahal perbuatan yang disangkakan sebagai penyebaran kebencian belum tentu terbukti. Berdasarkan kondisi tersebut tulisan ini akan membahas tentang arti penting pengaturan larangan penyebaran kebencian serta kedudukan norma persatuan sebagai dasar penilaian perbuatan penyebaran kebencian.

\section{Pembahasan}

\section{Kebebasan Berekspresi sebagai Hak Asasi Manusia dalam Instrumen Hukum Internasional dan Regulasi Nasional}

Kebebasan berekspresi menjadi isu penting bagi perlindungan hak asasi manusia. Instrumen hukum internasional penting terkait kebebasan berekspresi terdapat dalam International Covenant on Civil and Political Rights (ICCPR) atau Kovenan Internasional tentang Hak-hak Sipil dan Politik yang ditetapkan oleh Majelis Umum Perserikatan Bangsa-Bangsa dalam Resolusi 2200A (XXI) tertanggal 16 Desember 1966. Indonesia telah meratifikasi melalui UndangUndang Nomor 12 Tahun 2005 per 28 Oktober 2005. Ifdhal Kasim ${ }^{5}$ menjelaskan substansi ICCPR dalam 2 (dua) klasifikasi, kelompok hak tidak boleh dibatasi atau dikurangi pemenuhannya (non-derogable rights) oleh negara-negara pihak dan kelompok hak yang boleh dikurangi atau dibatasi pemenuhannya (derogable rights) oleh negara-negara pihak. Hak atas kebebasan menyatakan pendapat atau berekspresi sendiri masuk dalam derogable-rights. ${ }^{6}$ Klasifikasi kebebasan berekspresi sebagai derogable-rights tidak berarti eksistensi hak atas kebebasan berekspresi tidak penting. Hak atas kebebasan berekspresi diatur secara khusus dalam Article 19 Paragraph 2 dan paragraph 3. Pemahaman atas hak atas kebebasan berekspresi dipahami sebagai berikut:

"Article 19.

2. Everyone shall have the right to freedom of expression; this right shall include freedom to seek, receive and impart information and ideas of all

\footnotetext{
5 Ifdhal Kasim, Kovenan Hak-Hak Sipil dan Politik: Sebuah Pengantar Bahan Bacaan Kursus HAM untuk Pengacara XI Tahun 2007, Lembaga Studi dan Advokasi Masyarakat, https://lama.elsam.or.id/downloads/1365566878_Kovenan_SIPOL_MateriKursusHAMELSAM.pdf, di akses 28 Februari 2020

6 Id.
} 
kinds, regardless of frontiers, either orally, in writing or in print, in the form of art, or through any other media of his choice."7 (Setiap orang berhak atas kebebasan untuk menyatakan pendapat; hak ini termasuk kebebasan untuk mencari, menerima dan memberikan informasi dan pemikiran apapun, terlepas dari pembatasan-pembatasan secara lisan, tertulis, atau dalam bentuk cetakan, karya seni atau melalui media lain sesuai dengan pilihannya ${ }^{8}$ )

Article 19 Paragraph 2 ICCPR tersebut lebih memberikan jaminan atas kebebasan berekspresi dalam penyalurannya. Hak atas kebebasan berekspresi pada ketentuan hukum ini berkaitan erat dengan pihak lain yang menerima informasi. Komentar Umum 10 atas Article 19 Paragraph 2 ICCPR semakin menegaskan hal ini dengan menyatakan:

"Ayat 2 menentukan adanya perlindungan terhadap hak atas kebebasan berekspresi, termasuk tidak hanya kebebasan untuk "kebebasan untuk mencari, menerima dan memberikan informasi dan ide apapun", tetapi juga kebebasan untuk "mencari" dan "menerima" informasi dan ide tersebut "tanpa memperhatikan medianya" dan dalam bentuk apa pun..." 9

Berdasarkan Komentar Umum tersebut dapat diketahui bahwa hak atas kebebasan berekspresi memiliki tidak hanya dipahami sebagai hak untuk memberikan informasi akan tetapi rangkaian hak untuk mencari, menerima dan memberikan informasi. Pelaksanaan hak atas kebebasan berekspresi sebagai derogable rights ditegaskan dalam Article 19 Paragraph 3 ICCPR. Pembatasan hak atas kebebasan berekspresi harus dilakukan sesuai dengan hukum dan sepanjang diperlukan untuk 2 (dua) alasan utama, yaitu pertama Menghormati hak atau nama baik orang lain dan kedua Melindungi keamanan nasional atau ketertiban umum atau kesehatan atau moral umum. ${ }^{10}$ Artinya, pemahaman hak atas kebebasan berekspresi menurut ICCPR tetap memerhatikan penghormatan hak

$7 \quad$ United Nations, International Covenant on Civil and Political Rights Adopted by General Assembly of the United Nations on 19 December 1966, https://treaties.un.org/doc/publication/ unts/volume\%20999/volume-999-i-14668-english.pdf, di akses 28 Februari 2020

8 Ignatius Basis Susilo, et.al., Kompilasi Instrumen Internasional Hak Asasi Manusia Berikut Ratifikasinya dalam Peraturan Perndang-Undangan di Indonesia, Pusat Studi Hak Asasi Manusia Universitas Surabaya, 2003, Surabaya, hlm., 22

9 Komisi Nasional Hak Asasi Manusia, Komentar Umum Kovenan Internasional Hak Sipil dan Politik, Kovenan Internasional Hak Ekonomi Sosial dan Budaya, Komisi Nasiona Hak Asasi Manusia, Jakarta, 2009, hlm., 16

10 Ignatius Basis Susilo, et.al., Supra no. 8. 
asasi manusia orang lain serta situasi dan kondisi keamanan negara yang bersangkutan.

Terkait dengan pemahaman hak atas kebebasan berekspresi ini, Price ${ }^{11}$ menjelaskan hal penting yaitu

“...'free expression' is not only a set of principles and practices but also a set of institutions. These institutions include the mechanisms that exist in a society for the production and diffusion of information-the infrastructure of information flows- as well as the process by which people process information as they function as citizens or as members of a community."

Sebagai sebuah hak asasi manusia, hak atas kebebasan berekspresi sudah mendapatan pengakuan dalam instrumen internasional. Hanya saja arti penting kebebasan berekspresi sebagai suatu hak asasi manusia memerlukan penjabaran di suatu negara. Oleh karena itu pelaksanaan kebebasan berekspresi tidak terlepas dari regulasi nasional di suatu negara tidak terkecuali Indonesia.

Kebebasan berekspresi juga merupakan kebebasan yang sangat penting bagi bangsa Indonesia. Sejarah perjuangan bangsa mencatat bahwa kebebasan berekspresi menjadi wadah bagi pejuang kemerdekaan dalam merintis, menyamakan pandangan kebangsaan, memperkuat barisan perjuangan bahkan sampai pada kemerdekaan Indonesia. Penggunaan berbagai macam media komunikasi mulai dari surat kabar, pertemuan para tokoh dan penyebaran informasi melalui media komunikasi radio menunjukkan bahwa kebebasan berekspresi memiliki nilai strategis bagi perjuangan bangsa. Tidak heran jika pendiri bangsa (founding fathers) memasukkan kebebasan berekspresi sebagai hak asasi manusia yang sangat mendasar pada Undang-Undang Dasar Tahun 1945 (UUD 1945).

Hadirnya Pasal 28 UUD 1945 memberikan dasar utama akan pengakuan dan perlindungan hak untuk berekspresi yang dipahami dalam sebuah istilah "Kemerdekaan mengeluarkan pikiran dengan lisan dan tulisan dan sebagainya". Kebebasan berekspresi di dalam ketentuan hukum tersebut dipahami dalam bentuk tertentu yaitu hasil pikiran yang disampaikan secara lisan seperti dengan

11 Monroe E. Price, Free Expression, Globalism and the New Strategic Communication, Cambridge University Press, New York, 2015, hlm., 27 
ucapan atau perkataan ataupun dalam bentuk tulisan seperti melalui media cetak, poster, spanduk atau bentuk lain yang memuat dan menyampaikan pikiran. Apa yang diatur sebagai kemerdekaan mengeluarkan pikiran pada rumusan tersebut juga memiliki 2 (aspek) penting yaitu Pertama, harus dalam bentuk yang dapat dilihat atau dipahami oleh orang lain sebagai media informasi, serta kedua, ada tujuan orang lain untuk mengetahui informasi tersebut. Aspek pertama, menunjukkan adanya perwujudan pikiran seseorang yang dapat berbentuk apapun asalkan sudah dituangkan dalam media tertentu. Aspek kedua, menyangkut maksud dari dituangkannya informasi sehingga dari sudut pandang pembuat perbuatan itu dikehendaki olehnya untuk diketahui orang lain. Perihal orang lain harus tergerak oleh informasi yang diberikan, pada ketentuan Pasal 28 UUD 1945 sama sekali tidak memberikan pengaturan.

Hal yang penting untuk diketahui Pasal 28 UUD 1945 juga memberikan pembatasan terhadap kebebasan berekspresi, yaitu dilakukan dengan cara atau prosedur yang diatur dalam undang-undang. Sejauh ini undang-undang yang memberikan pengaturan terhadap kebebasan berekspresi terdapat dalam berbagai bidang menyangkut penyampaian informasi, antara lain Undang-Undang Nomor 40 Tahun 2009 tentang Pers (UU Pers), Undang-Undang Nomor 36 Tahun 2009 tentang Telekomunikasi (UU Telekomunikasi), Undang-Undang Nomor 20 Tahun 2002 tentang Penyiaran (UU Penyiaran), Undang-Undang Nomor 33 Tahun 2009 tentang Perfilman (UU Perfilman), Undang-Undang Nomor 28 Tahun 2014 tentang Hak Cipta (UU Hak Cipta) serta UU ITE. Masing-masing undang-undang memberikan pembatasan sendiri terkait bidang yang diatur. Pembatasan yang dilakukan sangat beragam bersesuaian dengan tujuan pengamanan informasi yang hendak disampaikan. Berikut bentuk pembatasan yang diberikan oleh tiap undang-undang:

Tabel 1: Pembatasan Kebebasan Berekspresi Dalam Undang-Undang

\begin{tabular}{ll}
\hline \multicolumn{1}{c}{ Undang-Undang } & \multicolumn{2}{c}{ Bentuk pembatasan } \\
\hline UU Pers & Larangan memuat iklan: \\
& a. merendahkan martabat suatu agama dan atau \\
& mengganggu kerukunan hidup antar umat beragama \\
& serta bertentangan dengan rasa kesusilaan masyarakat; \\
\hline
\end{tabular}


b. minuman keras, narkotika, psikotropika, dan zat adiktf lainnya dengan peraturan perundang-undangan yang berlaku;

c. peragaan wujud rokok dan atau penggunaan rokok. (Pasal 13)

UU Telekomunikasi Penyelenggara Telekomunikasi dilarang melakukan kegiatan usaha penyelenggaraan telekomunikasi yang bertentangan dengan kepentingan umum, kesusilaan, keamanan, atau ketertiban umum. (Pasal 21)

UU Penyiaran Isi Siaran wajib dijaga netralitasnya dan tidak boleh mengutamakan kepentingan golongan tertentu.

Isi siaran dilarang:

a. bersifat memfitnah, menghasut, menyesatkan dan/atau bohong;

b. menonjolkan unsur kekerasan, cabul, perjudian, penyalahgunaan narkotika dan obat terlarang; atau

c. mempertentangkan suku, agama, ras dan antargolongan. Isi siaran dilarang memperolokkan, merendahkan, melecehkan dan/atau mengabaikan nilai-nilai agama, martabat manusia Indonesia atau merusak hubungan internasional.

(Pasal 36 ayat (4), (5) dan (6))

UU Perfilman Setiap insan perfilman berkewajiban menjunjung tinggi nilai-nilai agama, etika, moral, kesusilaan dan budaya bangsa (Pasal 48 huruf d)

Setiap pelaku usaha perfilman berkewajiban menjunjung tinggi nilai-nilai agama, etika, moral, kesusilaan dan budaya bangsa dalam usaha perfilman (Pasal 50 ayat (2) huruf b)

UU Hak Cipta

Setiap orang dilarang melakukan Pengumuman, Pendistribusian, atau Komunikasi Ciptaan yang bertentangan dengan moral, agama, kesusilaan, ketertiban umum, atau pertahanan dan keamanan negara (Pasal 50)

Kekuatan hukum pencatatan Ciptaan dan produk Hak Terkait hapus karena melanggar norma agama, norma susila, ketertiban umum, pertahanan dan keamanan negara atau peraturan perundang-undangan yang penghapusannya dilakukan oleh Menteri. (Pasal 74 ayat (1) huruf d)

1. Larangan mendistribusikan dan/atau mentransmisikan dan/atau membuat dapat diaksesnya informasi elektronik yang memiliki muatan yang melanggar kesusilaan (Pasal 27 ayat (1)

2. Larangan mendistribusikan dan/atau mentransmisikan dan/atau membuat dapat diaksesnya informasi elektronik yang memiliki muatan perjudian (Pasal 27 ayat (2)

3. Larangan mendistribusikan dan/atau mentransmisikan dan/atau membuat dapat diaksesnya informasi elektronik yang memiliki muatan penghinaan dan/atau pencemaran nama baik (Pasal 27 ayat (3)

4. Larangan mendistribusikan dan/atau mentransmisikan dan/atau membuat dapat diaksesnya informasi elektronik yang memiliki muatan pemerasan dan/atau pengancaman (Pasal 27 ayat (4)

5. Menyebarkan berita bohong atau menyesatkan yang 


\begin{tabular}{|c|c|}
\hline & $\begin{array}{l}\text { merugikan konsumen (Pasal } 28 \text { ayat (1) } \\
\text { 6. menyebarkan informasi yang ditujukan untuk } \\
\text { menimbulkan rasa kebencian atau permusuhan individu } \\
\text { dan/atau kelompok masyarakat tertentu berdasarkan } \\
\text { suku, agama, ras dan antar golongan (SARA) (Pasal } 28 \\
\text { ayat (2) } \\
\text { 7. mengirimkan informasi elektronik yang berisi ancaman } \\
\text { kekerasan atau menakut-nakuti yang ditujukan secara } \\
\text { pribadi (Pasal 29) } \\
\text { (UU No. } 11 \text { Tahun 2008 jo UU No. } 19 \text { Tahun 2016) }\end{array}$ \\
\hline UU Pornografi & $\begin{array}{l}\text { Larangan menunjukkan atau menampilkan pornografi yang } \\
\text { secara eksplisit memuat persenggamaan termasuk } \\
\text { persenggamaan yang menyimpang, kekerasan seksual, } \\
\text { masturbasi atau onani, ketelanjangan atau tampilan yang } \\
\text { mengesankan ketelanjangan, alat kelamin atau pornografi } \\
\text { anak atau jasa pornografi (Pasal } 4 \text { UU No. } 44 \text { Tahun } 2008 \text { ) }\end{array}$ \\
\hline
\end{tabular}

Sumber: Diolah penulis dari berbagai sumber.

Pembatasan kebebasan berekspresi ditekankan pada larangan perbuatan yang muatannya menyerang kesusilaan dan ketertiban umum. Perbuatan yang termasuk dalam muatan yang menyerang kesusilaan sebagai contoh menyebarkan informasi yang bermuatan melanggar kesusilaan, cabul dan pornografi sedangkan ketertiban umum termasuk di dalamnya muatan yang merendahkan martabat agama, ras, golongan, perjudian, pengancaman, penghinaan/pencemaran nama baik, menyebarkan informasi untuk menimbulkan rasa kebencian atau permusuhan serta narkotika dan obat terlarang.

Secara khusus tentang penyebaran kebencian, tidak semua undang-undang mengatur tentang larangan penyebaran kebencian. Tidak semua undang-undang yang mengatur larangan penyebaran kebencian merumuskan secara eksplisit perbuatan menimbulkan rasa kebencian atau permusuhan namun ada juga yang dirumuskan secara implisit. Ketentuan hukum pidana terkait penyebaran kebencian antara lain Pasal 36 ayat (5) huruf a Undang-Undang Penyiaran dan Pasal 28 ayat (2) UU ITE. Ketentuan hukum lain yang mengatur penyebaran kebencian secara implisit antara lain Pasal 13 huruf a UU Pers ("mengganggu kerukunan hidup antar umat beragama"), Pasal 21 UU Telekomunikasi ("bertentangan dengan kepentingan umum,.. ketertiban umum") serta Pasal 46 ayat (3) jo Pasal 58 huruf d UU Penyiaran ("menyinggung perasaan dan/atau merendahkan kelompok lain"). Kepentingan yang hendak dilindungi dari 
perbuatan penyebaran kebencian atau permusuhan mengarah pada ketertiban umum masyarakat.

Berdasarkan ketentuan hukum tersebut tampak bahwa larangan atas penyebaran ujaran kebencian memiliki karakteristik berbeda dengann perbuatan pidana lainnya. Karakteristik perbuatan menyebarkan kebencian tidak sama dengan pencemaran nama baik, penghinaan dan penodaan yang selama ini dikenal dalam hukum pidana. Perbuatan menyebarkan kebencian pada hakikatnya mengancam kerukunan hidup antar anggota masyarakat memunculkan konflik bahkan kerusuhan rasial sebagaimana ditegaskan Penjelasan Umum UU PDRE. Perihal perbedaan sejak semula menjadi perhatian utama dari pendiri bangsa pada saat merumuskan dasar negara Indonesia, secara khusus Sila Persatuan Indonesia. Pendiri bangsa menegaskan persatuan Indonesia dipahami sebagai semangat kebangsaan yang menyatukan setiap anggota masyarakat tanpa meniadakan perbedaan yang ada. Sebagaimana ditegaskan dalam semboyan Bhineka Tunggal Ika Tan Hana Dhrama Manrwa, yaitu walaupun berbeda dalam pluralitas tetap berada dalam bingkai kesatuan. ${ }^{12}$ Senada dengan pandangan ini, Soediman Kartohadiprodjo sebagaimana dikutip Shidarta pun mengungkapkan bahwa Pancasila memiliki inti kekeluargaan yang mengakui perbedaan individu dalam semangat persatuan. ${ }^{13}$ Soekarno menegaskan bahwa adanya persatuan yang membentuk sebuah bangsa didasarkan pada 2 (dua) hal penting yaitu kehendak untuk hidup bersama (Le desir d'etre ensemble) dan persamaan watak (gemeinschaft). ${ }^{14}$ Kehendak untuk hidup bersama ini memunculkan rasa kebersamaan dari setiap individu yang berada di suatu wilayah tertentu untuk bekerjasama dalam penhormatan peran tiap anggota. Sedangkan persamaaan watak tidak terbatas pada kesamaan adat akan tetapi kesamaan bangsa yang menghendaki masyarakat adil dan makmur. Yudi Latif

12 Erika \& Mangku, Dewa Gede Sudika, Politik Hukum Pancasila dalam Paradigma Nilai-Nilai Sosial Kultural Masyarakat Indonesia. Jurnal Pandecta, Vol 9 No 1 2014, hlm., 44.

13 Shidarta, Membaca Ulang Pemaknaan Keadilan Sosial Dalam Gagasan Revolusi Hukum, Jurnal Veritas et Justitia, Vol 1 No 1 2015, hlm., 23

14 PSP UGM Yogyakarta \& Yayasan TIFA, Pancasila Dasar Negara: Kursus Presiden Soekarno tentang Pancasila, Aditya Media bekerjasama dengan Pusat Studi Pancasila (PSP) UGM Yogyakarta dan TIFA. Yogyakarta, 2008, hlm., 97-102 
menjelaskan perihal keberadaan Indonesia atas persatuan ini melalui cultural nationalism, yaitu:

"suatu konsepsi kebangsaan yang memandang bahwa kemanusiaan secara inheren diorganisasikan ke dalam komunitas historis, yang masing-masing diwarnai oleh kekuatan uniknya sendiri, yang diekspresikan melalui kekhasan budaya, berbasiskan pada persada alamiah (natural homelands), dengan tata-pemerintahan yang khas."15

Persatuan dalam pemahaman inilah yang membuat perbedaan tetap hidup dalam kebersamaan. Persatuan tidak menuntut peleburan perbedaan yang ada namun meminta kerelaan diri untuk menerima perbedaan yang ada bersatu padu demi menjaga kehidupan bersama. Negara pun hadir sebagai wujud persatuan bangsa yang memiliki beragam perbedaan memiliki misi mempertemukan nilai, kepentingan, dan cita-cita bersama. ${ }^{16}$ Regulasi merupakan tindakan pemerintah yang penting demi menjaga kebersamaan dalam keragaman tersebut. Keberadaan hukum digunakan sebagai alat untuk mengayomi (guardianship) ${ }^{17}$ masyarakat. Dengan demikian persatuan Indonesia yang menjadi sila ketiga Pancasila mengilhami lahirnya norma persatuan Indonesia yang memiliki karakteristik yang berbeda jika dibandingkan dengan persatuan bangsa/negara lainnya.

\section{Perkembangan Regulasi Penyebaran Kebencian di Indonesia}

KUHP merupakan ketentuan hukum pidana yang paling lama berlaku di Indonesia. Sejak disahkannya, Wetboek van Strafrecht yang berlaku pada tanggal 8 Maret 1942 maka KUHP menjadi pedoman dalam menilai suatu perbuatan sebagai perbuatan pidana (Undang-Undang 1946 No. 1 Pasal I). Perihal penyebaran kebencian jika dikaji berdasarkan ketentuan hukum pidana yang terdapat dalam KUHP dapat dilihat berdasarkan kepentingan hukum publik yang hendak dilindungi dan dipertahankan oleh pembentuk undang-undang ${ }^{18}$ dalam hal ini

15 Yudi Latif, Negara Paripurna: Historitas, Rasionalitas, dan Aktualitas Pancasila, Gramedia Pustaka Utama, Jakarta, 2012, hlm., 358-359

16 Id.

17 E. Fernando M. Manullang, The Purpose of Law, Pancasila and Legality According to Ernst Utrecht: A Critical Reflection", Indonesia Law Review, Vol 5 No 2 2015, hlm., 193.

18 Christina Widowati, Hukum Sebagai Norma Sosial memiliki Sifat Mewajibkan, Jurnal Hukum Adil, Vol 4 No. 1 2013, hlm., 161. 
KUHP. Kepentingan tersebut tidak lain merupakan ketertiban umum yang tidak hanya dimiliki oleh orang perorangan akan tetapi setiap orang sebagai manusia.

Setidaknya terdapat 2 (dua) bentuk larangan terkait erat dengan larangan penyebaran kebencian kepada orang lain dan/atau golongan masyarakat, yaitu pertama, larangan perbuatan menyatakan permusuhan, kebencian atau penghinaan terhadap golongan rakyat Indonesia berdasarkan ras, negeri asal, agama, tempat asal, keturunan, kebangsaan atau kedudukan menurut hukum tata negara. Kedua, Larangan perbuatan menyatakan permusuhan, penyalahgunaan atau penodaan terhadap suatu agama yang dianut di Indonesia atau dengan maksud agar orang tidak menganut agama apapun yang bersendikan Ketuhanan Yang Maha Esa. Kedua pengaturan tersebut memiliki ruang lingkup yang berbeda namun mengatur substansi perbuatan yang sama, pernyataan permusuhan atau kebencian. Perbedaan terdapat dalam hal obyek yang diserang oleh perbuatan pertama berupa golongan rakyat Indonesia sedangkan perbuatan kedua berupa agama yang dianut di Indonesia. Jika dicermati dengan seksama, perbuatan pertama memiliki ruang lingkup lebih luas jika dibandingkan dengan perbuatan kedua, bahkan perbuatan pertama mencakup perbuatan kedua mengingat agama menjadi bagian dari istilah "golongan rakyat Indonesia" dan disebutkan secara eksplisit dalam Pasal 156 KUHP. Berdasarkan asas lex specialist derogat legi generalis maka Pasal 156a KUHP lebih diberlakukan pada perbuatan pidana permusuhan terhadap agama yang dianut di Indonesia karena mengatur lebih khusus.

Hal yang menarik dalam perbuatan pidana sebagaimana diatur dalam Pasal 156 KUHP lebih menitik beratkan pada larangan terhadap 3 (tiga) macam perbuatan yaitu (1) Menyatakan perasaan permusuhan, (2) Menyatakan perasaan kebencian dan (3) Menyatakan perasaan penghinaan. Ketiga bentuk perbuatan tersebut dirumuskan secara alternatif yang berarti perbuatan tersebut dapat berdiri sendiri-sendiri sebagai sebuah perbuatan pidana. Pemahaman terhadap masing-masing perbuatan ternyata memiliki makna yang berbeda karena pada dasarnya istilah "permusuhan", "kebencian" dan "penghinaan" memiliki pemahaman yang berbeda. Istilah "permusuhan" diartikan sebagai "perihal 
sesuatu yang mengancam (kesehatan, keselamatan), yang merusakkan atau perseteruan"19, istilah "kebencian" berarti "perasaan sangat tidak suka"20 sedangkan istilah "penghinaan" berarti "proses atau cara merendahkan kedudukannya (pangkatnya, martabatnya)". ${ }^{21}$ Jika diamati dari ketiga istilah ini maka diperoleh pemahaman bahwa kebencian menjadi awal atau sebab dari dua perbuatan lainnya. Seseorang yang memusuhi orang lain pasti diawali dari perasaan benci, begitu pula dengan penghinaan yang menjadi wujud dari ungkapan kebencian baik secara langsung (lisan) ataupun tidak langsung (tulisan). Berdasarkan pemahaman tersebut dapat dipahami keberadaan kebencian menjadi hal yang sangat membahayakan karena dapat menimbulkan perbuatan pidana yang lainnya.

Jauh setelah kemerdekaan Indonesia, awal Januari 1965 Pemerintah mengeluarkan sebuah ketetuan hukum penting terkait dengan toleransi terhadap keberagaman yaitu Penetapan Presiden No. 1/PNPS Tahun 1965 tentang Pencegahan Penyalahgunaan dan/atau Penodaan Agama. Bab Konsiderans Penetapan Presiden yang ditetapkan pada 27 Januari 1965 tersebut menegaskan 2 (dua) pertimbangan utama yaitu (a) Pembentukan peraturan untuk mencegah penyalahgunaan atau penodaan agama dibutuhkan untuk mendukung pengamanan Negara dan masyarakat, cita-cita Revolusi Nasional Semesta dan (b) penetapan presiden diperlukan sebagai langkah pengamanan revolusi dan ketentuan masyarakat yang jelas. dari kedua pertimbangan tersebut terlihat dengan jelas bahwa pemerintah lebih berfokus pada pembentukan peraturan $a$ quo diarahkan untuk kepentingan keamanan Negara dan masyarakat menuju citacita revolusi Nasional. Stabilitas sosial menjadi penekanan utama bagi terwujudnya revolusi nasional mengingat kondisi politik pada saat itu masih berfokus pada penghayatan Pancasila dan UUD 1945 pasca Dekrit Presiden 1959. Kedua pertimbangan tersebut lebih jelas dijabarkan dalam Penjelasan Umum yang menguraikan 5 (lima) hal antara lain:

\footnotetext{
19 Departemen Pendidikan Nasional, Kamus Besar Bahasa Indonesia Pusat Bahasa, Gramedia Pustaka Utama, Jakarta, 2015, hlm., 168

$20 \quad$ Id., hlm., 334

$21 \quad$ Id., hlm., 499
} 
Pertama, Sejalan dengan UUD 1945 Ketuhanan Yang Maha Esa merupakan dasar moral yang memastikan adanya kesatuan nasional yang berasas keagamaan. Kedua, timbul aliran-aliran atau organisasi-organisasi kebatinan/kepercayaan masyarakat yang bertentangan dengan ajaran-ajaran dan hukum agama bahkan melanggar hukum, memecah persatuan dan menodai Agama sehinigga membahayakan agama-agama yang ada. Ketiga, demi kewaspadaan Nasional dalam Demokrasi Terpimpin Penetapan Presiden merupakan jaminan ketenteraman beragama dan menunaikan ibadah menurut Agamanya masingmasing. Keempat, Penetapan Presiden ini bertujuan untuk mencegah agar tidak terjadi penyelewengan dari ajaran agama yang dianggap sebagai ajaran pokok serta melindungi ketentraman beragama dari penodaan/penghinaan serta dari ajaran-ajaran untuk tidak memeluk agama yang bersendikan Ketuhanan Yang Maha Esa. Kelima, Peraturan ini tidak dimaksudkan uintuk mengganggu hak hidup agama-agama yang sudah diakui oleh Pemerintah sebelum Penetapan Presiden ini diundangkan. Kelima pertimbangan tersebut menunjukkan bahwa Pemerintah berinisiatif untuk memberikan perlindungan terhadap agama sebagai ajaranajaran pokok dari upaya penodaan/penghinaan agama. Ketentuan hukum ini memberikan konsekuensi dengan penambahan Pasal 156a pada KUHP yang memberikan 2 (dua) larangan pokok yaitu perbuatan pidana menyatakan permusuhan, penyalahgunaan atau penodaan terhadap suatu agama yang dianut di Indonesia dan Perbuatan Pidana membuat orang tidak menganut agama apapun juga yang bersendikan ke-Tuhanan Yang Maha Esa.

Pemberlakuan ketentuan hukum tersebut terkait erat dengan larangan terhadap perbuatan Penyebaran kebencian terutama tentang kehidupan beragama. Pasal 4 UU No. 1/PNPS/1965 (Pasal 156a KUHP) menyatakan larangan terhadap perbuatan yang dengan sengaja di muka umum mengeluarkan perasaan atau melakukan perbuatan yang pada pokoknya bersifat permusuhan terhadap suatu agama yang dianut di Indonesia. Ketentuan hukum tersebut memiliki ruang lingkup yang jelas dalam Penjelasan Pasal 4 UU a quo bahwa

“... Cara mengeluarkan perasaan atau melakukan perbuatan dapat dilakukan dengan lisan, tulisan ataupun perbuatan lain. Huruf a, tindak 
pidana yang dimaksudkan disini, ialah yang semata-mata (pada pokoknya) ditujukan kepada niat untuk memusuhi atau menghina. Dengan demikian, maka uraian-uraian tertulis maupun lisan yang dilakukan secara obyektif, zakelijk dan ilmiah mengenai sesuatu agama yang disertai dengan usaha untuk menghindari adanya kata-kata susunan kata-kata yang bersifat permusuhan atau penghinaan, bukanlah tindak pidana menurut pasal ini."22

Penjelasan Pasal 4 UU a quo menunjukkan pemahaman atas perbuatan permusuhan baik dari sisi substansi perbuatan maupun ruang lingkup perbuatan. Substansi perbuatan permusuhan terhadap agama di sini harus dilakukan dengan adanya niat untuk memusuhi atau menghina sehingga bentuk kesalahan yang disyaratkan adalah kesengajaan dalam bentuk kesengajaan sebagai maksud. Hal tersebut tampak dengan jelas pada penjelasan Pasal 4 bahwa "perbuatan itu (pada pokoknya) ditujukan untuk memusuhi atau menghina" sehingga pelaku memiliki maksud utama untuk melakukan permusuhan atau penghinaan. Pemahaman tersebut dipertegas kembali dalam bagian penjelasan Pasal 4 tersebut bahwa pengecualian terhadap perbuatan permusuhan/penghinaan jika perbuatan itu dinilai secara obyektif, zakelijk dan ilmiah tidak ditujukan untuk permusuhan atau penghinaan. Maksud tersebut tampak dengan jelas dari kehati-hatian seseorang dalam menggunakan kata-kata yang tepat dan tidak bersifat permusuhan. Ruang lingkup dari perbuatan permusuhan terhadap agama pun dalam ketentuan hukum ini tidak terbatas pada bentuk perbuatan lisan termasuk di dalamnya perbuatan tertulis atau perbuatan lain. Penggunaan frasa "perbuatan lain" ini membuka kemungkinan bagi perbuatan permusuhan yang dilakukan dengan bentuk lain yang mungkin terjadi di masa yang akan datang. Berada dalam konteks ini sebenarnya penyebaran informasi yang dilakukan melalui media internet termasuk dalam ruang lingkup perbuatan permusuhan terhadap agama sebagaimana dimaksud dalam ketentuan hukum a quo.

Perkembangan pengaturan ketentuan hukum selanjutnya terdapat dalam beberapa undang-undang pidana khusus antara lain Undang-Undang Nomor 39 Tahun 1999 tentang Hak Asasi Manusia (UU HAM), UU ITE dan UU PDRE. Masing- 
masing pengaturan terkait dengan perbuatan penyebaran rasa permusuhan atau kebencinan diuraikan sebagai berikut:

a. Penyebaran kebencian sebagai Pelanggaran Hak Asasi Manusia

Semangat Reformasi yang timbul pada pertengahan tahun 1998 menjiwai upaya perlindungan hak asasi manusia yang selama ini masih belum mendapatkan pengaturan yang jelas, utamanya dalam produk Undang-Undang. Hak Asasi Manusia didefinisikan sebagai secara yuridis formal sebagai "seperangkat hak yang melekat pada hakikat dan keberadaan manusia sebagai makhluk Tuhan Yang Maha Esa dan merupkaan anugerah-Nya yang wajib dihormati, dijunjung tinggi oleh negara, hukum, Pemerintah dan setiap orang demi kehormatan serta perlindungan harkat dan martabat manusia." (Pasal 1 angka 1 UU HAM). Keberadaan hak asasi manusia bukan merupakan pemberian dari hukum melainkan pemberian Tuhan yang melekat secara esensi (bersifat universal) ${ }^{23}$ dalam kemanusiaan manusia itu sendiri. Sepintas pemahaman Pasal 1 angka 1 UU HAM ini cenderung menempatkan hak asasi manusia sebagai hak yang paling ampuh dan tidak mungkin dikurangi bahkan dibatasi dalam pemenuhannya, padahal tidak demikian adanya. UU HAM mencatat bahwa perlindungan hak asasi manusia memiliki 2 (dua) sisi utama yang saling melengkapi dan berjalan seimbang, yaitu Hak Dasar Manusia dan Kewajiban Dasar Manusia.

Tercatat dalam Hak Dasar Manusia yang dilindungi antara lain: Hak untuk hidup, Hak Mengembangkan Diri, Hak Memperoleh Keadilan, Hak Atas Kebebasan Pribadi, Hak atas Rasa Aman, Hak atas Kesejahteraan, Hak Turut Serta dalam Pemerintahan, Hak Wanita dan Hak Anak. Sedangkan yang termasuk dalam Kewajiban Dasar Manusia antara lain (1) patuh pada peraturan perundang-undangan, hukum tidak tertulis dan hukum internasional serta (2) menghormati hak asasi manusia orang lain, moral, etika, dan tata tertib kehidupan bermasyarakat, berbangsa dan bernegara.

23 Muktiono, Kritik Konseptualisasi Pemegang Hak dan Pemegang Kewajiban Dalam UndangUndang Hak Asasi Manusia, Jurnal Arena Hukum, Vol 8 No 3 2015, hlm., 350. 
Pemahaman akan 2 (dua) sisi Hak Asasi Manusia tersebut menjadi tanda beda bagi pemahaman hak asasi manusia yang diakui dan dilindungi penerapannya di Negara Indonesia. Pemenuhan hak asasi manusia apapun bentuknya tetap harus selaras dengan peraturan perundang-undangan yang berlaku serta serasi ketika berdampingan dengan hak asasi manusia yang diiringi orang lain.

Hak asasi manusia yang terkait dengan perlindungan terhadap perbuatan penyebaran kebencian dapat dilihat dari 2 (dua) sisi hak asasi manusia yang dimiliki, oleh orang yang mengeluarkan pendapat dan orang lain yang mendapatkan informasi (pendapat) dari orang pertama tersebut. Kebebasan mengeluarkan pendapat terkait dengan beberapa bentuk hak asasi manusia antara lain:

Tabel 2: Pengaturan Hak Asasi Kebebasan Berpendapat dalam UU HAM

\begin{tabular}{|c|c|}
\hline Hak Asasi terkait Kebebasan Berpendapat & Ketentuan Hukum \\
\hline $\begin{array}{l}\text { Hak atas perlindungan bagi pengembangan pribadi untuk } \\
\text { meningkatkan kualitas hidupnya }\end{array}$ & Pasal 12 \\
\hline $\begin{array}{l}\text { Hak untuk berkomunikasi yang diperlukan untuk mengembangkan } \\
\text { diri dan lingkungan sosialnya }\end{array}$ & Pasal 14 ayat (1) \\
\hline $\begin{array}{l}\text { Hak untuk mengolah dan menyampaikan informasi dengan } \\
\text { mengguakan segala jenis sarana yang tersedia }\end{array}$ & Pasal 14 ayat (2) \\
\hline Hak untuk memperjuangkan pengembangan dirinya & Pasal 15 \\
\hline Hak untuk memilih dan berkeyakinan politik & Pasal 23 ayat (1) \\
\hline $\begin{array}{l}\text { Hak untuk bebas mempunyai, mengeluarkan dan menyebarluaskan } \\
\text { pendapat sesuai hati nuraninya, secara lisan atau tulisan melalui } \\
\text { media cetak maupun elektronik dengan memperhatikan nilai-nilai } \\
\text { agama, kesusilaan, ketertiban, kepentingan umum dan keutuhan } \\
\text { negara }\end{array}$ & Pasal 23 ayat (2) \\
\hline Hak untuk menyampaikan pendapat di muka umum & Pasal 25 \\
\hline Hak untuk diperlakukan sama di depan hukum & Pasal 29 ayat (2) \\
\hline $\begin{array}{l}\text { Hak untuk mengajukan pendapat kepada pemerintah dalam rangka } \\
\text { pelaksanaan pemeritahan yang bersih, efektif dan efisien baik lisan } \\
\text { maupun dengan tulisan sesuai dengan ketentuan peraturan } \\
\text { perundang-undangan }\end{array}$ & Pasal 44 \\
\hline $\begin{array}{l}\text { Hak anak untuk berpikir dan berekspresi sesuai dengan tingkat } \\
\text { intelektualitas dan usianya dibawah bimbingan orang tua dan atau } \\
\text { wali }\end{array}$ & Pasal 55 \\
\hline $\begin{array}{l}\text { Hak anak untuk memberikan informasi sesuai dengan tingkat } \\
\text { intelektualitas dan usia demi pengembagan dirinya sepanjang sesuai } \\
\text { dengan nilai-nilai kesusilaan dan kepatutan }\end{array}$ & Pasal 60 ayat (2) \\
\hline $\begin{array}{l}\text { Hak atas perlindungan untuk memperoleh pendidikan, } \\
\text { mencerdaskan dirinya dan meningkatkan kualitas hidupnya }\end{array}$ & Pasal 12 \\
\hline $\begin{array}{l}\text { Hak untuk mengembangkan dan memperoleh manfaat dari ilmu } \\
\text { pengetahuan dan teknologi, seni dan budaya }\end{array}$ & Pasal 13 \\
\hline $\begin{array}{l}\text { Hak untuk memperoleh informasi yang diperlukan untuk } \\
\text { pengembangan pribadi dan lingkungan sosialnya }\end{array}$ & Pasal 14 ayat (1) \\
\hline
\end{tabular}




\begin{tabular}{ll}
\hline $\begin{array}{l}\text { Hak untuk mencari, memperoleh, memiliki dan menyimpan } \\
\text { informasi dengan segala jenis sarana yang tersedia. }\end{array}$ & Pasal 14 ayat (2) \\
\hline $\begin{array}{l}\text { Hak atas perlindungan diri pribadi, keluarga, kehormatan, martabat } \\
\text { dan hak miliknya }\end{array}$ & Pasal 29 ayat (1) \\
\hline Hak untuk diperlakukan sama di depan hukum & Pasal 29 ayat (2) \\
\hline $\begin{array}{l}\text { Hak wanita untuk memperoleh informasi dalam pendidikan di } \\
\text { semua jenjang }\end{array}$ & Pasal 48 \\
\hline $\begin{array}{l}\text { Hak anak untuk memperoleh perlindungan dari orang tua, keluarga, } \\
\text { masyarakat dan Negara }\end{array}$ & Pasal 52 ayat (1) \\
\hline $\begin{array}{l}\text { Hak anak untuk mendapatkan pendidikan dan pengajaran dalam } \\
\text { ranka pengembangan pribadinya sesuai dengan minat, bakat dan } \\
\text { tingkat kecerdasannya }\end{array}$ & Pasal 60 ayat (1) \\
\hline $\begin{array}{l}\text { Hak untuk mencari dan menerima informasi sesuai dengan tingkat } \\
\text { intelektualitas dan usianya demi pengembangan dirinya sepanjang } \\
\text { sesuai dengan nilai-nilai kesusilaan dan kepatutan }\end{array}$ & Pasal 60 ayat (2) \\
\hline $\begin{array}{l}\text { Sumber: Diolah penulis dari berbagai sumber. } \\
\end{array}$
\end{tabular}

Jika dicermati lebih lanjut, hak kebebasan berpendapat dalam UU HAM juga menunjukkan pemahaman yang sama dengan Article 19 Paragraph 2 ICCPR. Penekanan hak kebebasan berpendapat meliputi kebebasan untuk mencari, menerima dan memberikan informasi yang ada pada diri seseorang kepada orang lain seperti ditegaskan Pasal 14 ayat (2) UU HAM. Uniknya, UU HAM menegaskan pentingnya hak atas kebebasan berekspresi tersebut sebagai pemenuhan kebutuhan pengembangan diri secara personal dan kebutuhan untuk bermasyarakat. Hak atas kebebasan berpendapat sebagai pemenuhan kebutuhan akan pengembangan diri tampak sebagai upaya peningkatan kualitas hidup (Pasal 12) serta upaya aktualisasi diri (Pasal 13, Pasal 14 ayat (1), Pasal 29, Pasal 48 dan Pasal 60). Hak atas kebebasan berpendapat sebagai kebutuhan bermasyarakat dijelaskan sebagai upaya untuk mengembangkan lingkungan sosial (Pasal 12, Pasal 14 ayat (1) dan Pasal 60 ayat (2).

Tampak dengan jelas perlindungan hak asasi manusia terkait dengan informasi menjadi bagian yang sangat penting. Tidak ada satu bidang yang luput dari hadirnya hak asasi atas informasi ini dalam berbagai macam bentuknya, seperti hak untuk memilih dalam bidang politik, agama, pendidikan sampai pada kehidupan sehari-hari. Hanya saja di sisi lain hak atas informasi yang aman juga dibutuhkan oleh orang lain yang menerima informasi tersebut. Informasi haruslah informasi yang bermanfaat bagi 
penerima informasi terutama pada hal pengembangan diri. Berdasarkan pada pemahaman ini maka hak asasi manusia dalam pelaksanaan hak asasi berekspresi merupakan hak asasi manusia yang "bersifat particular". ${ }^{24}$ Pelaksanaan hak berekspresi sangat bergantung pada substanasi informasi dan tujuan diberikannya informasi tersebut.

Hal yang menarik bahwa dalam hak asasi manusia atas informasi baik bagi pemberi maupun penerima informasi dibatasi pada nilai-nilai agama, kesusilaan, kepatutan, keutuhan dan kepentingan negara. Pasal 28I ayat (2) UUD 1945 menegaskan bahwa setiap orang berhak bebas dari perlakuan diskriminatif atas dasar apapun. Ketentuan ini juga menjadi batasan bagi hak atas informasi untuk tidak mengurangi atau mengganggu hak orang lain untuk bebas dari diskriminasi. Pasal 28J UUD 1945 jelas memberikan kejelasan bahwa apapun bentuk hak asasi manusia itu harus dipahami secara berimbang dan sesuai aturan hukum. Pendangan ini berbeda sama sekali dengan konsep Hak Asasi manusia yang dipahami dalam Deklarasi Universal Hak Asasi Manusia. Kharlie menegaskan perbedaan ini "the difference is that in obligation of every person to respect human rights of others in the society, nation and state, as well as the ability to restrict freedom through legislation, as well as considerations of morality, religious values, security, public order in a country democratic." 25 Hak asasi manusia tidak boleh digunakan untuk menyerang hak asasi manusia milik orang lain. Penggunaan hak asasi manusia tetap harus disesuaikan dengan nilai agama, moral, pertimbangan keamanan dan ketertiban umum.

Batasan tersebut pada dasarnya dapat digunakan dalam menilai arti penting pengaturan perbuatan penyebaran kebencian. Kebencian terhadap sesuatu atau obyek tertentu baik itu berupa orang, entitas atau hal lain merupakan kebencian yang dilarang ketika melanggar nilai-nilai agama,

24 Suparman Marzuki, Perspektif Mahkamah Konstitusi tentang Hak Asasi Manusia: Kajian Tiga Putusan Mahkamah Konstitusi No. 065/PUU-II/2004; Nomor 102/PUU-VII/2009 dan Nomor 140/PUU-VII/2009, Jurnal Yudisial Vol 6 No 3 2013, hlm., 191.

25 Ahmad Tholabi Kharlie, Human Rights in Indonesian Constitution Amandment, Jurnal Cita Hukum, Vol I No 1 2013, hlm., 161. 
kesusilan, kepatutan, keutuhan dan kepentingan negara. Perbuatan penyebaran kebencian melalui internet dipandang sebagai yang tidak dilarang ketika besesuaian dengan nilai agama, kesusilaan, kepatutan, keutuhan dan kepentingan negara sebagai contoh informasi yang menekankan untuk membenci perbuatan zinah dan perkosaan, informasi yang menguraikan bahaya dari pornografi, dan informasi yang mengutuk keras faham separatisme dan diskriminasi. Terkait dengan hal inilah maka penyebaran kebencian harus dipandang sebagai upaya untuk melanggar nilai agama, kesusilaan, kepatutan, keutuhan dan kepentingan negara. Dengan demikian kepentingan yang dilindungi bukan bersifat privat melainkan bersifat publik. Penilaian atas suatu perbuatan yang menebarkan kebencian tidak boleh hanya dirasakan oleh satu orang saja melainkan menjadi kepentingan umum.

b. Penyebaran Kebencian sebagai Substansi Informasi yang Dilarang

Pembentukan UU ITE pada dasarnya memiliki keunikan terutama dalam hal model pengaturan yang dipilih dan substansi pengaturannya sendiri. Pembentuk undang-undang mempertimbangkan urgensitas kepastian hukum dan perlindungan hukum bagi pengguna internet ketika mengingat begitu banyak perbuatan yang merugikan terjadi dengan memanfaatkan teknologi informasi. Pembentuk undang-undang menyadari bahwa pembentukan ketentuan hukum yang menjadi dasar bagi transaksi elektronik bukanlah perkara yang mudah mengingat ruang lingkup dan bentuk perbuatan yang terjadi dapat mengalami perkembangan begitu cepat seiring dengan perkembangan teknologi.

Perumusan perbuatan yang dilarang lebih bersifat umum dengan harapan mampu menampung kepentingan yang lebih besar. Model perumusan seperti ini di sisi lain menimbulkan permasalahan dari sisi pemahaman ruang lingkup dari ketentuan hukum. Ketentuan hukum pasal 28 ayat (2) UU ITE menunjukkan bahwa penyebaran informasi yang ditujukan untuk menimbulkan rasa kebencian atau permusuhan individu dan/atau kelompok masyarakat tertentu berdasarkan SARA merupakan perbuatan yang dilarang. Rumusan ketentuan hukum tersebut memiliki ruang lingkup yang sangat luas 
karena bukan hanya menyangkut kepentingan individu melainkan kepentingan kelompok masyarakat tertentu dengan alasan SARA.

Substansi pengaturan tersebut menjadi lebih luas jika dibandingkan dengan perlindungan Hak Asasi Manusia dalam UU HAM yang memberikan batasan bahwa kepentingan umumlah yang diatur sebagai hak asasi manusia. Substansi pengaturan Pasal 28 ayat (2) UU ITE sendiri lebih memberikan perlindungan dari perbuatan yang menimbulkan rasa benci atau permusuhan kepada individu dan/atau kelompok masyarakat tertentu berdasarkan SARA.

Unsur perbuatan pidana sebagaimana diatur dalam Pasal 28 ayat (2) jo. Pasal 45 ayat (2) UU ITE terdiri dari unsur subyektif yaitu "dengan sengaja”, dan unsur obyektif yaitu "tanpa hak menyebarkan informasi yang ditujukan untuk menimbulkan rasa kebencian atau permusuhan individu dan/atau kelompok masyarakat berdasarkan suku, agama, ras, dan antargolongan (SARA)". Berdasarkan kedua unsur perbuatan pidana tersebut tampak bahwa unsur obyektif menjadi penekanan dari rumusan ketentuan hukum pidana ini (bestandeel delict). Penggunaan istilah "ditujukan untuk menimbulkan rasa kebencian atau permusuhan" dalam Pasal 28 ayat (2) UU ITE dalam kajian semantik melalui proses asosiasi ${ }^{26}$ mengandung arti bahwa penyebarluasan informasi tidak hanya sebagai pernyataan ekspresi atau perasaan saja. Pernyataan perasaan memang memiliki muatan kebencian akan tetapi pernyataan tersebut mengganggu kehidupan bersama bangsa Indonesia. Demikian pula dalam hal penyebaran informasi tersebut ditujukan untuk menimbulkan rasa kebencian dan permusuhan dari masyarakat secara luas. Berdasarkan tujuan penyebarluasan melalui media elekronik tersebut maka larangan perbuatan menyebarkan informasi yang ditujukan untuk menimbulkan rasa kebencian dan permusuhan bersifat antisipatif. Terkait ada atau tidak adanya rasa kebencian atau permusuhan tidak perlu disyaratkan dalam pembuktian cukup bahwa tujuan dari pelaku untuk menyebarluaskan

26 Ikhwan M. Said, Kajian Semantik Terhadap Produk Hukum Tertulis Di Indonesia, Jurnal Mimbar Hukum Vol 24 No 2 2012, hlm., 191. 
rasa kebencian atau permusuhan. Bentuk rumusan ketentuan hukum seperti ini sangat dimungkinkan dalam hukum pidana.

Remmelink menjelaskan bentuk rumusan perbuatan pidana didasarkan pada bahaya yang akan atau selalu ditimbulkan dibedakan menjadi 2 (dua) delik yaitu delik yang menimbulkan bahaya konkret dan delik yang menimbulkan bahaya abstrak. ${ }^{27}$ Delik yang menimbulkan bahaya abstrak dipahami sebagai delik yang dirumuskan sebagai tindak pidana berdasarkan pengalaman perbuatan ini berisiko pelanggaran ketentuan-ketentuan hukum tanpa merumuskan secara rinci kepentingan hukum apa yang rentan terhadap risiko ini. Berbeda dengan delik yang menimbulkan bahaya konkrit bahwa bahaya ini sudah disebutkan secara langsung sebagai sesuatu yang terjadi sehingga perbuatan tersebut dilarang. Perumusan Pasal 28 ayat (2) UU ITE dirumuskan dengan bentuk delik yang menimbulkan bahaya abstrak. Hal tersebut diketahui dari istilah "ditujukan untuk menimbulkan rasa kebencian atau permusuhan" sehingga akibat rasa kebencian atau permusuhan menjadi hal yang berisiko terjadi dari penyebaran informasi. Sebagai bentuk rumusan perbuatan pidana maka rumusan pasal 28 ayat (2) UU ITE menekankan arti penting pada dilarangnya perbuatan dan unsur apa yang harus dibuktikan oleh penuntut umum. ${ }^{28}$ Dilarangnya perbuatan menimbulkan rasa kebencian atau permusuhan melalui media internet jelas telah diatur dalam UU ITE sehingga dapat disebut sebagai perbuatan pidana. Dampak pengaturan dari bentuk delik yang menimbulkan bahaya abstrak terdapat dalam hal penuntutan. Penuntut umum tidak perlu membuktikan adanya akibat telah timbul rasa kebencian atau permusuhan sebagai akibat dari penyebaran informasi tersebut. Penuntut umum cukup membuktikan bahwa perbuatan pelaku telah nyata ditujukan untuk menimbulkan rasa kebencian dan permusuhan atas dasar SARA.

27 Jan Remmelink, Hukum Pidana: Komentar atas Pasa-Pasal Terpenting dari Kitab UndangUndang Hukum Pidana Belanda dan Padanannya dalam Kitab Undang-Undang Hukum Pidana Indonesia, Gramedia Pustaka Utama, Jakarta, 2013, hlm., 62-63

28 Septa Candra, Perumusan Perbuatan Pidana dalam Peraturan Perundang-undangan di Indonesia, Jurnal Hukum Prioris Vol 3 No 3 2013, hlm., 115 
c. Penyebaran kebencian sebagai bentuk Perbuatan Diskriminasi Ras dan Etnis

Pemberlakuan UU PDRE memberikan sebuah pertanyaan tersendiri bagi pengakuan keberagaman dan kerukunan hidup masyrakat Indonesia yang berbhineka tunggal ika. Pengaturan UU PDRE seolah menegaskan bahwa keberagaman menjadi hal yang selama ini penting bagi kehidupan bangsa akan tetapi lupa diberikan pengaturan dalam Undang-Undang. Secara historis yuridis perbuatan diskriminasi dianggap sebagai perbuatan yang terlarang oleh UUD 1945 dilanjutkan dengan Pasal 156 KUHP. Artinya, keberadaan pengaturan perbuatan diskriminasi sangatlah penting baik dari dimensi politik hukum maupun dimensi politik kriminal. Dimensi politik hukum memberikan penekanan perumusan perbuatan diskriminasi sebagai perbuatan yang dilarang menjadi hal yang penting sebagai perwujudan asas legalitas. Di sisi lain, dimensi politik kriminal keberadaan larangan perbuatan diskriminasi menunjuk pada upaya pencegahan terjadinya kejahatan yang dimaksud di kemudian hari. ${ }^{29}$ Pasal 156 KUHP ternyata mengatur perbuatan menyatakan permusuhan, kebencian atau penghinaan terhadap suatu atau beberapa golongan. Beberapa bentuk perbuatan tersebut pada dasarnya tidak berbeda jika dibandingkan dengan rumusan Pasal 156 KUHP yang menegaskan larangan pernyataan perasaan permusuhan, kebencian atau penghinaan terhadap golongan rakyat Indonesia. Golongan rakyat yang dimaksudkan yaitu tiap bagian rakyat Indonesia yang memiliki perbedaan atas dasar ras, negeri asal, agama, tempat asal, keturunan, kebangsaan atau kedudukan menurut hukum tata negara.

Hanya saja pemberlakuan UU PDRE memberikan nuansa baru terhadap larangan tersebut karena memiliki tujuan diskriminasi. Diskriminasi yang dimaksudkan bukanlah sekedar tidak memberikan sikap yang sama pada seseorang. Istilah "diskriminasi" berarti "pembedaan perlakuan terhadap sesama warga negara (berdasarkan warna kulit, golongan, suku, ekonomi,

29 Sari Mandiana, Konsepsi Pertanggung Jawab Pidana Sebagai Sistem Normatif, Jurnal Prioris Vol 5 No 2 2016, hlm., 138-139 
agama, dsb)" 30 berdasarkan pemahaman istilah ini maka perbuatan memiliki sebab utama yaitu perasaan benci atas kondisi lahiriah yang ada pada diri seseorang. UU PDRE lebih spesifik memberikan ruang lingkup diskriminasi ras dan etnis pada Pasal 1 angka 1 sebagai:

"segala bentuk pembedaan, pengecualian, pembatasan atau pemilihan berdasarkan ras dan etnis yang mengakibatkan pencabutan atau pengurangan pengakuan, perolehan, atau pelaksanaan hak asasi manusia dan kebebasan dasar dalam suatu kesetaraan di bidang sipil, politik, ekonomi, sosial dan budaya."

Berdasarkan definisi tersebut maka diskriminasi ras dan etnis merupakan perbuatan yang dengan sengaja dilakukan untuk menunjukkan kebencian terhadap orang lain atau golongan atau kelompok tertentu di bidang sipil, politik, ekonomi, sosial dan budaya. Perbuatan menunjukkan kebencian disini terbatas pada perbuatan pembedaan, pengecualian, pembatasan atau pemilihan dengan alasan ras atau etnis. Akibatnya pun ditentukan adanya pencabutan, pengurangan pengakuan, perolehan atau pelaksanaan hak asasi manusia dan kebebasan dasar dalam kelima bidang tadi.

Penyebaran kebencian jika dipadukan dengan pemahaman diskriminasi ras dan etnis tersebut dapat digolongkan dalam perbuatan awal dari perwujudan diskriminasi bahkan perbuatan diskriminasi itu sendiri. Pasal 4 huruf b UU PDRE menyatakan 4 (empat) bentuk perbuatan menunjukkan kebencian atau rasa benci kepada orang antara lain:

1. "membuat tulisan atau gambar untuk ditempatkan, ditempelkan atau disebarluaskan di tempat umum atau tempat lainnya yang dapat dilihat atau dibaca oleh orang lain;

2. berpidato atau mengungkapkan, atau melontarkan kata-kata tertentu di tempat umum atau tempat lainnya yang dapat didengar orang lain;

3. mengenakan sesuatu pada dirinya berupa benda, kata-kata, atau gambar di tempat umum atau tempat lainnya yang dapat dibaca oleh orang lain; atau

4. melakukan perampasan nyawa, penganiayaan, pemerkosaan, perbuatan cabul, pencurian dengan kekerasan, atau perampasan kemerdekaan berdasarkan diskriminasi ras dan etnis."

30 Supra no. 19. hlm., 944 
Keempat bentuk perbuatan menunjukkan kebencian tersebut pada dasarnya merupakan perbuatan yang dilakukan secara nyata dan di tempat umum agar dapat diketahui oleh masyarakat. Walaupun UU PDRE sama sekali tidak mensyaratkan adanya respon dari masyarakat baik berupa dukungan atau penolakan dari perbuatan menunjukkan kebencian. Hal yang penting untuk dipahami bahwa dalam Pasal 4 huruf b UU PDRE sasaran atau tujuan dari perbuatan menunjukkan kebencian dapat dibedakan dalam 2 (dua) sasaran, yaitu:

1. orang yang menjadi korban secara langsung;

Perbuatan menunjukkan kebencian yang ditujukan secara langsung pada korban dapat berupa membuat tulisan atau gambar yang menyerang perbedaan ras dan etnis dari korban yang membaca secara langsung, melakukan perampasan nyawa, pengaiayaan, pemerkosaan, perbuatan cabul, pencurian dengan kekerasan atau perampasan kemerdekaan dari korban dengan alasan perasaan benci ras dan etnis yang dimiliki korban.

2. orang lain atau masyarakat umum;

Sisi lain dari perbuatan menunjukkan kebencian justru mengusahakan dukungan dari masyarakat umum terhadap upaya diskriminasi. Tiga bentuk perbuatan awal dari Pasal 4 huruf b UU PDRE merupakan perbuatan yang ditujukan kepada masyarakat umum untuk mengetahui perasaan benci dari pelaku. Perbuatan tersebut justru sangat berbahaya karena mengancam keamanan dan ketertiban umum. Walaupun tidak ditujukan secara langsung kepada korban, perbuatan tersebut justru menciptakan suasana diskriminasi ras dan etnis yang lebih luas.

Perbuatan menunjukkan kebencian dalam UU PDRE memiliki sifat khusus karena ditujukan pada diskriminasi ras dan etnis saja. Dengan demikian maka UU PDRE menjadi lex specialist dari Pasal 156 KUHP untuk pengaturan larangan pernyataan permusuhan kepada orang atau kelompok berdasarkan ras dan etnis. 


\section{Norma Persatuan sebagai Batasan Perbuatan Pidana Penyebaran Kebencian}

Norma persatuan merupakan norma yang jarang diketahui oleh masyarakat Indonesia. Norma yang secara umum dikenal seperti halnya norma kesusilaan, norma kesopanan, norma Ketuhanan merupakan norma-norma yang banyak dikenal mengingat banyaknya kasus yang terjadi. Keberadaan norma kesusilaan dan kesopanan tidak lain bersumber pada nilai Kemanusiaan yang adil dan beradab sebagai bentuk pengakuan hakikat kemanusiaan yang dihayati oleh Bangsa Indonesia. Begitu pula dengan norma Ketuhanan yang Maha Esa mengarahkan pandangan masyarakat Indonesia untuk berperilaku sesuai dengan ajaran yang bersendikan Ketuhanan Yang Maha Esa. Hanya saja dengan perkembangan teknologi informasi yang begitu cepat nilai-nilai asing banyak berdatangan memengaruhi nilai yang ada sehingga menggangu keragaman Indonesia. ${ }^{31}$ Pemahaman akan norma persatuan sebagai nilai sosial sangat dibutuhkan untuk menjaga dan menanggulangi bahaya tersebut.

Persatuan Indonesia merupakan sila ketiga yang membawa tanda beda bangsa Indonesia yang sadar akan keragaman diri manusia. Keragaman diri manusia merupakan suatu hal yang diterima secara kodrat dari Tuhan Yang Maha Esa sehingga keberadaannya merupakan suatu keniscayaan. Sila Persatuan Indonesia dalam sejarah pemikiran Pendiri Bangsa (the founding fathers) tidak lahir secara otomatis. Keberadaan persatuan Indonesia dilatarbelakangi akan kesadaran perbedaan yang ada sebagai suatu hal yang lumrah sehingga harus diterima dengan lapang dada untuk sama-sama bekerjasama mewujdukan citacita Bangsa Indonesia, masyarakat adil dan makmur sebagai idee negara. ${ }^{32}$ Persatuan Indonesia dalam Pancasila saat ditempatkan sebagai ideologi bangsa dapat mempersatukan semua masyarakat serta menyelaraskan semua kepentingan yang berbeda. ${ }^{33}$ Persatuan Indonesia tidaklah menyamakan perbedaan yang ada dan menolak perbedaan yang ada melainkan menerima

31 Kamarudin Hasan, Pancasila dan Arsitektur Negara Hukum Indonesia, Jurnal Digest Epistema Vol 4 No 1 2013, hlm., 28.

32 Supra no. 14.

33 Gabriela Febrianty, Philosophy, Pancasila and Modern Technology, Jurnal Yuridika Vol 29 No 2 2014, hlm., 10-11. 
perbedaaan yang ada sebagai suatu karunia Tuhan yang Maha Esa untuk dapat hidup secara bersama-sama. Kesadaran akan perbedaan yang dimiliki oleh tiap individu menjadi hal yang penting dalam memahami manusia seutuhnya berdasarkan Pancasila. Kesadaran tersebut menimbulkan pemahaman bahwa sebagaimana diri sendiri diciptakan unik begitu pula orang lain juga memiliki keunikan.

Keberadaan norma persatuan memang tidak disebutkan secara eksplisit dalam ketentuan hukum pidana. Pemberlakuan norma persatuan mendasari larangan Pasal 28 ayat (2) UU ITE sebagai perbuatan yang mengancam kepentingan hukum masyarakat untuk akan ketertiban hukum. Pemahaman akan pentingnya persatuan menjadi penting sebagai ukuran sekaligus batasan bagi seseorang yang ingin menyebarluaskan informasi di media massa, terutama media internet. Setiap orang harus mampu memahami isi dari informasi yang disampaikannya memiliki risiko tertentu sudah dapat diperkirakan sebelumnya. Jika menilik Pasal 28 ayat (2) UU ITE tampak dengan jelas bahwa pembentuk undang-undang mensyaratkan pelaku sudah mengetahui dan menghendaki (willens en weten) isi atau substansi informasi yang disampaikannya mengandung kebencian dan dapat dipahami sebagai upaya membuat orang lain melakukan kebencian atau permusuhan pada orang dan/atau kelompok lain atas dasar SARA.

Perbuatan menyebarkan kebencian atau permusuhan berdasarkan SARA melalui internet jika dipahami berdasarkan norma persatuan sudah seharusnya merupakan perbuatan pidana dalam bentuk kejahatan. Perbuatan menyebarkan kebencian atau permusuhan berdasarkan SARA merupakan perbuatan yang menyerang kepentingan umum dalam hal ini ketertiban umum untuk hidup bersama dalam keberagaman. UU ITE hanya menyebutkan bahwa Pasal 28 ayat (2) UU ITE sebagai tindakan yang dilarang dan tidak menegaskan perbuatan ini sebagai perbuatan yang tercela sehingga harus diantisipasi dan ditanggulangi dengan sesegara mungkin oleh aparat penegak hukum. Dampak dari tidak adanya penetapan suatu perbuatan sebagai kejahatan atau pelanggaran terdapat dalam hal penindakan, secara khusus penindakan perbuatan a quo di luar wilayah Indonesia. Penindakan perbuatan menyebarkan kebencian atau permusuhan 
berdasarkan SARA yang dilakukan oleh warga negara Indoensia di wilayah negara lain tidak dapat dilakukan (asas nasionalitas aktif tidak berfungsi) ${ }^{34}$ karena penindakan di luar territorial negara lain perlu penetapan perbuatan sebagai kejahatan.

Pemahaman terhadap norma persatuan ini juga begitu penting dalam penanganan ujaran kebencian (hate speech) oleh Kepolisian Negara Republik Indonesia. Surat Edaran Kapolri Nomor SE/06/X/2015 tentang Penanganan Ujaran Kebencian (SE Kapolri PUK) merupakan pedoman bagi kepolisian untuk menangani perkara ujaran kebencian yang sangat berbahaya. SE Kapolri PUK menegaskan bahwa perbuatan ujaran kebencian memiliki dampak merendahkan harkat martabat manusia dan kemanusiaan (Pasal 2 huruf b). Ujaran kebencian ini merupakan perbuatan yang mendorong terjadinya perbuatan lain yang lebih berbahaya dalam skala yang lebih luas antara lain kebencian kolektif, pengucilan, diskriminasi, kekerasan, dan pembantaian etnis atau genosida atas kelompok yang menjadi sasaran. Ujaran kebencian dalam SE Kapolri PUK ini ditempatkan sebagai perbuatan yang melahirkan perbuatan pidana lainnya sehingga harus ditanggulangi dengan segera. Hal yang menarik dari SE Kapolri PUK ini terletak dalam dasar kebencian yang digunakan serta media komunikasi yang digunakan.

SE Kapolri PUK merinci 11 aspek yang dapat dijadikan bahan atau tema perbuatan ujaran kebencian yaitu suku, agama, aliran keagamaan, keyakinan/kepercayaan, ras, antar golongan, warna kulit, etnis, gender, kaum difabel (cacat) dan orientasi seksual. Kesebelas alasan tersebut menunjukkan bahwa SE Kapolri PUK ingin mengakomodasi semua ketentuan hukum tentang ujaran kebencian yang tidak hanya didasarkan pada perbedaan agama melainkan isu kemasyarakatan yang terdapat dalam ketentuan hukum pidana khusus serta hak asasi manusia. Perbuatan ujaran kebencian pun dapat dilakukan dalam 7 (tujuh) bentuk antara lain orasi kegiatan kampanye, spanduk atau banner, jejaring

\footnotetext{
34 Supriyadi, Penetapan Tindak Pidana sebagai Kejahatan dan Pelanggaran dalam UndangUndang Pidana Khusus, Jurnal Mimbar Hukum Vol 27 No 3 2015, hlm., 397.
} 
media sosial, penyampaian pendapat di muka umum (demonstrasi), ceramah keagamaan, media masa cetak maupun elektronik dan pamflet.

Secara umum, SE Kapolri PUK memang menjadi pedoman operasional bagi internal kepolisian hanya tetap memiliki dampak bagi masyarakat karena terkait erat dengan aspek dan media yang digunakan. Kegiatan orasi kegiatan kampanye semula sebagai bagian dari kegiatan politik memperoleh batasan sepanjang tidak menunjukkan ujaran kebencian kepada orang lain atau kelompok lain. Tidak dapat dipungkiri masalah diskriminasi yang bermuara pada kebencian ras dan etnis merupakan hal yang sangat sensitive bagi masyarakat Indonesia. Jejaring media sosial yang semula menawarkan kebebasan informasi juga mendapatkan pantauan sebagai media menyebarkan ujaran kebencian. Penyampaian informasi kampanye yang berisikan ujaran kebencian akan mengakibatkan partisipasi politik menjadi rendah sehingga pelaksanaan demokrasi menjadi tidak sehat. ${ }^{35}$ Begitu pula dengan penyampaian pendapat di muka umum serta media massa baik cetak maupun elektronik mendapatkan batasan apabila dinilai berpotensi menimbulkan diskriminasi atau kebencian atau permusuhan pada orang lain atau kelompok lainnya. Hal yang unik dalam SE Kapolri PUK ini, ceramah keagamaan pun tidak boleh dijadikan sarana untuk menyebarkan kebencian atau permusuhan padahal ceramah keagamaan sifatnya terbatas pada umat tertentu.

Keberadaan SE Kapolri PUK tersebut harus ditangani secara berimbang oleh Kepolisian dengan mengedepankan keadilan substantif daripada keadilan prosedural. Keadilan prosedural cenderung memenuhi rumusan ketentuan hukum pidana tanpa menghiraukan norma persatuan yang diakui. Penanganan perkara dugaan penyebaran kebencian atau permusuhan yang mendasarkan diri pada keadilan substantif akan membentuk penyelesaian hukum yang bersandar pada hukum yang mendalami hati masyarakat. ${ }^{36}$ Penilaian suatu informasi dapat dinilai sebagai ujaran kebencian atau permusuhan padahal maksud awal dari penyampaian informasi untuk memberikan pendapat, opini atau kritikan.

35 Benny Sumardiana, Formulasi Kebijakan Penanganan Tindak Pidana Berbasis Isu Sara dalam Pemilihan Umum, Jurnal Pandecta Vol 11 No 1 2016, hlm., 83-85.

36 M. Syamsudin, Keadilan Prosedural dan Substantif dalam Putusan Sengketa Tanah Magersari: Kajian Putusan Nomor 74/PDT.G/2009/PNYK, Jurnal Yudisial Vol 7 No 1 2014, hlm., 22. 
Penilaian yang tidak berimbang dan hati-hati akan berakibat kriminalisasi pada perbuatan penyampaian informasi yang pada hakikatnya merupakan hak asasi manusia. Oleh karena itu pemahaman terhadap norma persatuan oleh Kepolisian menjadi hal yang sangat penting.

Arti penting dari noma persatuan sebagai batasan dan ukuran penilaian informasi yang disampaikan melalui media internet terletak pada perlindungan atas keberagaman dan kebersamaan masyarakat. Norma persatuan menghendaki informasi yang dibuat haruslah informasi yang menghargai perbedaan sebagai hal yang utama. Penerimaan informasi pun harus disaring dengan rasa tanggung jawab untuk menjaga semangat kebersamaan. Norma persatuan mengajak setiap individu atau kelompok untuk mengedepankan keadilan yang kejujuran yang bersumber dari hati nurani ${ }^{37}$ terhadap apa yang seharusnya dilakukan kepada diri dan orang lain/kelompok lain. Akhirnya, informasi pun disajikan untuk mempererat hubungan satu dengan lainnya. Pelanggaran terhadap norma persatuan merupakan penyampaian informasi yang ditujukan untuk menimbulkan rasa benci atau permusuhan pada orang lain secara individu dan/atau kelompok. Tujuan penyampaian informasi ini dapat dilihat bukan hanya dari sisi niat dari pelaku semata akan tetapi tampak dalam substansi informasi yang diberikan oleh pelaku. Sisi obyektif dari informasi ini harus digali dengan jelas menunjukkan tujuan dari pemberian informasi tersebut. Kepolisian harus mampu memberikan penjelasan yang tepat dan obyektif terhadap informasi mana yang dinilai berisiko menimbulkan kebencian atau permusuhan.

\section{Penutup}

Perbuatan penyebaran kebencian selalu bersingungan dengan 2 (dua) macam hak asasi manusia, kebebasan berekspresi dan hak asasi manusia untuk bebas dari diskriminasi. Oleh karena itu larangan terhadap perbuatan penyebaran kebencian dapat dipandang sebagai bentuk pembatasan terhadap kebebasan berekspresi yang diatur dalam berbagai undang-undang terkait. Pengaturan

37 Budiono Kusumohamidjojo, Adakah: Veritas et Iustitia?, Jurnal Veritas et Justitia Vol 1 No 1 2015, hlm., 10 
larangan perbuatan ujaran kebencian menunjukkan maksud pembentuk undangundang untuk melindungi norma persatuan di masyarakat. Keberadaan norma persatuan tidak secara eksplisit disebutkan dalam ketentuan hukum akan tetapi menjadi kepentingan hukum yang dlindungi oleh pembentuk undang-undang yang dalam perwujudannya diwujudkan dalam 3 (tiga) bentuk pemahaman yaitu penyebaran kebencian sebagai pelanggaran hak asasi manusia, penyebaran kebencian sebagai substabsi informasi yang dilarang dan penyebaran kebencian sebagai perbuatan diskriminasi ras dan etnis. Norma persatuan menjadi norma yang cocok dijadikan tolok ukur atau pedoman dalam menentukan suatu pernyataan atau perbuatan menyatakan kebencian. Norma persatuan menghadirkan cara pandang yang tepat tentang semangat kebangsaan, tidak dalam tataran konsep saja melainkan tataran penerapan hukum sebagai pedoman dalam menangani perkara secara bijak. Rumusan perbuatan pidana penyebaran kebencian sebagaimana diatur dalam Pasal 28 ayat (2) UU ITE dan dilanjutkan dengan penganan kepolisian SE Kapolri PUK sudah seharusnya didasarkan pada pemahaman norma persatuan. Oleh karena itu norma kesusilaan perlu dicantumkan dalam rumusan perbuatan pidana atau setidaknya penjelasan ketentuan hukum a quo. Hal tersebut memiliki dampak penting untuk menjaga obyektivitas penegak hukum dalam menilai suatu informasi sebagai ungkapan kebencian atau permusuhan yang bersifat negatif.

\section{Daftar Pustaka}

\section{Buku:}

Departemen Pendidikan Nasional, Kamus Besar Bahasa Indonesia Pusat Bahasa, Gramedia Pustaka Utama, Jakarta, 2015.

Ignatius Basis Susilo, et.al., Kompilasi Instrumen Internasional Hak Asasi Manusia Berikut Ratifikasinya dalam Peraturan Perndang-Undangan di Indonesia, Pusat Studi Hak Asasi Manusia Universitas Surabaya, 2003, Surabaya. 
Jan Remmelink, Hukum Pidana: Komentar atas Pasa-Pasal Terpenting dari Kitab Undang-Undang Hukum Pidana Belanda dan Padanannya dalam Kitab Undang-Undang Hukum Pidana Indonesia, Gramedia Pustaka Utama, 2013.

Komisi Nasional Hak Asasi Manusia, Komentar Umum Kovenan Internasional Hak Sipil dan Politik, Kovenan Internasional Hak Ekonomi Sosial dan Budaya, Komisi Nasiona Hak Asasi Manusia, Jakarta, 2009.

PSP UGM Yogyakarta \& Yayasan TIFA Jakarta, Pancasila Dasar Negara: Kursus Presiden Soekarno tentang Pancasila, Aditya Media bekerjasama dengan Pusat Studi Pancasila (PSP) UGM Yogyakarta dan TIFA Jakarta, Yogyakarta, 2008.

Yudi Latif, Negara Paripurna: Historitas, Rasionalitas, dan Aktualitas Pancasila, Gramedia Pustaka Utama, Jakarta, 2012.

\section{Jurnal:}

Ahmad Tholabi Kharlie, Human Rights in Indonesian Constitution Amandment, Jurnal Cita Hukum Vol. I No. 12013.

Benny Sumardiana, Formulasi Kebijakan Penanganan Tindak Pidana Berbasis Isu Sara dalam Pemilihan Umum, Jurnal Pandecta Vol. 11 No.1, 2016.

Budiono Kusumohamidjojo, Adakah: Veritas et Iustitia?, Jurnal Veritas et Justitia Vol. 1 No. 1, 2015.

Christina Widowati, Hukum Sebagai Norma Sosial memiliki Sifat Mewajibkan, Jurnal Hukum Adil Vol. 4 No. 12013.

E. Fernando M. Manullang, The Purpose of Law, Pancasila and Legality According to Ernst Utrecht: A Critical Reflection. Indonesia Law Review, Vol. 5 No. 22015.

Erika \& Mangku, Dewa Gede Sudika, Politik Hukum Pancasila dalam Paradigma Nilai-Nilai Sosial Kultural Masyarakat Indonesia, Jurnal Pandecta Vol. 9 No. 12014

Gabriela Febrianty, Philosophy, Pancasila and Modern Technology, Jurnal Yuridika Vol. 29 No. 2, 2014.

Ikhwan M. Said, Kajian Semantik Terhadap Produk Hukum Tertulis Di Indonesia, Jurnal Mimbar Hukum Vol. 24 No. 22012.

Kamarudin Hasan, Pancasila dan Arsitektur Negara Hukum Indonesia, Jurnal Digest Epistema Vol. 4 No. 1, 2013.

M. Syamsudin, Keadilan Prosedural dan Substantif dalam Putusan Sengketa Tanah Magersari: Kajian Putusan Nomor 74/PDT.G/2009/PNYK, Jurnal Yudisial Vol. 7 No. 1, 2014.

Muktiono, Kritik Konseptualisasi Pemegang Hak dan Pemegang Kewajiban Dalam Undang-Undang Hak Asasi Manusia, Jurnal Arena Hukum Vol. 8 No. 32015.

Sari Mandiana, Konsepsi Pertanggung Jawab Pidana Sebagai Sistem Normatif, Jurnal Prioris Vol. 5 No. 2, 2016.

Septa Candra, Perumusan Perbuatan Pidana dalam Peraturan Perundangundangan di Indonesia, Jurnal Hukum Prioris Vol. 3 No. 32013.

Shidarta, Membaca Ulang Pemaknaan Keadilan Sosial Dalam Gagasan Revolusi Hukum, Jurnal Veritas et Justitia Vol. 1 No. 12015.

Suparman Marzuki, Perspektif Mahkamah Konstitusi tentang Hak Asasi Manusia: Kajian Tiga Putusan Mahkamah Konstitusi No. 065/PUU-II/2004; Nomor 
102/PUU-VII/2009 dan Nomor 140/PUU-VII/2009, Jurnal Yudisial Vol. 6 No. 32013.

Supriyadi, Penetapan Tindak Pidana sebagai Kejahatan dan Pelanggaran dalam Undang-Undang Pidana Khusus. Jurnal Mimbar Hukum Vol. 27 No. 3, 2015

\section{Internet:}

Ifdhal Kasim, Kovenan Hak-Hak Sipil dan Politik: Sebuah Pengantar Bahan Bacaan Kursus HAM untuk Pengacara XI Tahun 2007, Lembaga Studi dan Advokasi Masyarakat, https://lama.elsam.or.id/downloads/1365566878_Kovenan_ SIPOL_MateriKursusHAM-ELSAM.pdf, di akses 28 Februari 2020.

Nina Atmasari, ed., Bantah Lakukan Ujaran Kebencian, Ahmad Dhani Anggap Cuitannya Wajar, https://news.harianjogja.com/read/2018/12/11/500/ 958068/bantah-lakukan-uahmad-dhani-anggap-cuitannya-wajar-, diakses 28 Februari 2020.

Pebriansyah Ariefana, Isi Lengkap Putusan Banding Kasus Ujaran Kebencian Ahmad Dhani, https://www.suara.com/news/2019/03/13/174931/isilengkap-putusan-banding-kasus-ujaran-kebencian-ahmad-dhani, diakses 28 Februari 2020.

Rivki, Alfian Tanjung: Lepas di Kasus PDI Dihukum karena Fitnah Jokowi, https://news.detik.com/berita/d-4060805/alfian-tanjung-lepas-di-kasuspdip-dihukum-karena-fitnah-jokowi, diakses 28 Februari 2020.

United Nations, International Covenant on Civil and Political Rights Adopted by General Assembly of the United Nations on 19 December 1966, https://treaties.un.org/doc/publication/unts/volume\%20999/volume999-i-14668-english.pdf, di akses 28 Februari 2020.

\section{Peraturan Perundang-undangan:}

Undang-Undang Dasar Republik Indonesia Tahun 1945.

Undang-Undang Nomor 39 Tahun 1999 tentang Hak Asasi Manusia.

Undang-Undang Nomor 11 Tahun 2008 tentang Informasi dan Transaksi Elektronik.

Undang-Undang Nomor 19 Tahun 2016 tentang Perubahan Undang-Undang Nomor 11 Tahun 2008 tentang Informasi dan Transaksi Elektronik.

Undang-Undang Nomor 40 Tahun 2008 tentang Penghapusan Diskriminasi Ras dan Etnis.

Undang-Undang Nomor 12 Tahun 2005 tentang Pengesahan International Covenant on Civil and Political Rights (Kovenan Internasional Tentang HakHak Sipil dan Politik).

Undang-Undang Nomor 40 Tahun 1999 tentang Pers.

Undang-Undang Nomor 36 Tahun 1999 tentang Telekomunikasi.

Undang-Undang Nomor 32 Tahun 2002 tentang Penyiaran.

Undang-Undang Nomor 28 Tahun 2014 tentang Hak Cipta

Undang-Undang Nomor 33 Tahun 2009 tentang Perfilman.

Kitab Undang-Undang Hukum Pidana.

Surat Edaran Kapolri Nomor SE/06/X/2015 tentang Penanganan Ujaran Kebencian. 